\title{
Design of a P-\&-O algorithm based MPPT charge controller for a stand-alone 200W PV system
}

\author{
Salman Salman, Xin Al and Zhouyang WU
}

\begin{abstract}
Solar cells convert sun light into electricity, but have the major drawbacks of high initial cost, low photo-conversion efficiency and intermittency. The current-voltage characteristics of the solar cells depend on solar insolation level and temperature, which lead to the variation of the maximum power point (MPP). Herein, to improve photovoltaic (PV) system efficiency, and increase the lifetime of the battery, a microcontroller-based battery charge controller with maximum power point tracker (MPPT) is designed for harvesting the maximum power available from the PV system under given insolation and temperature conditions. Among different MPPT techniques, perturb and observe (P\&O) technique gives excellent results and thus is used. This work involves the design of MPPT charge controller using DC/DC buck converter and microcontroller. A prototype MPPT charge controller is tested with a $200 \mathrm{~W}$ PV panel and lead acid battery. The results show that the designed MPPT controller improves the efficiency of the PV panel when compared to conventional charge controllers.
\end{abstract}

Keywords: PV system, Maximum power point tracker (MPPT), Perturb and observe (P\&O) technique, Charge controller, Microcontroller

\section{Introduction}

Solar energy is one of the most important renewable energy resources because it is inexhaustible and eco-friendly, and has been used to provide light, heat and electricity $[1,2]$. Solar PV modules have two major problems of low efficiency and intermittency, i.e. their efficiency of converting sun light into electric power is generally less than $17 \%$, and the generated electric power changes with weather conditions [3-5]. Moreover, PV cell characteristics (I-V or V-P) are nonlinear and changes with insolation and temperature. In stand-alone solar PV systems, the PV modules and batteries are the most expensive components. When the batteries are directly connected to the PV modules, there is no protection against overcharging and consequently, battery life-span decreases. To protect batteries from overcharging charge controllers can be used, though conventional charge controllers do not operate PV modules at MPP, resulting in lower efficiency. To improve the efficiency, it is desirable to operate the PV module at peak power point to deliver maximum power to the batteries.

MPPT techniques are used to extract the maximum output power from PV modules [6-10], and different DC/ DC converter topologies are used to transfer maximum power from PV modules to loads/ batteries [11, 12]. Different techniques of MPPT have been proposed, e.g. open circuit voltage methods $[13,14]$, short circuit current methods $[15,16]$, fuzzy logic technique $[17,18]$, perturb and observe (P\&O) [19-21], incremental conductance (IC) technique [22-24].

In this work, a MPPT charge controller based on the $\mathrm{P} \& \mathrm{O}$ technique is designed, to operate a fixed PV module at MPP. The hardware implementation of the designed $200 \mathrm{~W}$ MPPT charge controller is carried out and the prototype is tested for the PV charging system. The results show that such type of MPPT controller improves the efficiency of PV panels when compared to conventional charge controllers.

\footnotetext{
* Correspondence: aixin@ncepu.edu.cn

State Key Laboratory of Alternate Electrical Power System with Renewable Energy Sources, North China Electric Power University, Beijing 102206, China
} 

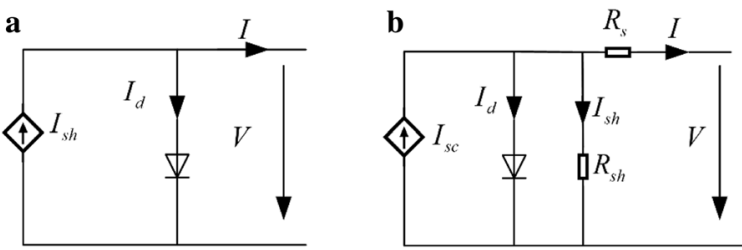

Fig. 1 Equivalent circuit of Solar cell a ideal, b practical

\section{Case description}

The renewable energy sources, especially solar cells are attracting the interests of researchers worldwide due to their direct conversion of light into electricity. However, the high-cost, low photo-conversion efficiency and intermittency are still need to be addressed. The case study involves the design of MPPT charge controller using DC/ DC buck converter and microcontroller. A prototype MPPT charge controller is tested with a 200W PV panel and lead acid battery. The as-designed MPPT controller improves the efficiency of the PV panel when compared to conventional charge controllers.

\section{Discussion and Evaluation}

\subsection{Photovoltaic system}

In PV panels, PV cells convert sunlight into electrical energy, which is one of the best approaches for achieving electrical power for long duration. The conversion from sun light to electrical power greatly depends on various factors such as the insolation level and cell efficiency. Solar PV systems are used today in many applications such as lighting, battery charging, water pumping, and satellite power systems etc. [25].

\subsection{PV cell equivalent circuit}

An ideal PV cell can be presented by a current source with a diode connected in parallel. In the ideal case, the series and shunt resistances are considered to be zero and infinite, respectively. However, in real system, both the series and shunt resistances have finite values and must be considered. In Fig. 1, both the ideal and practical equivalent

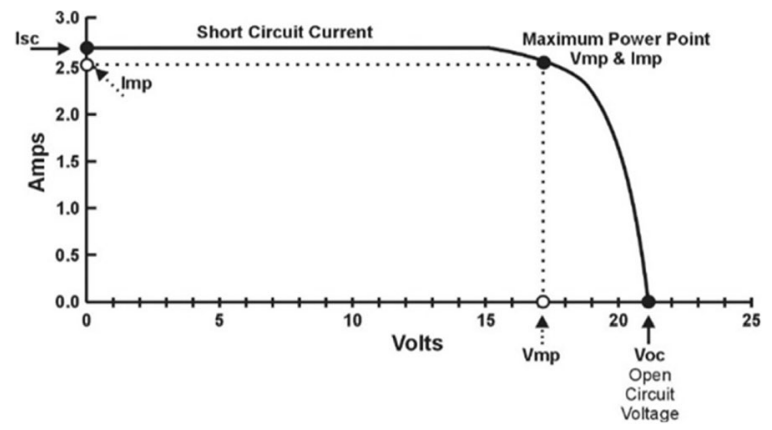

Fig. 2 General I-V curve of PV cell

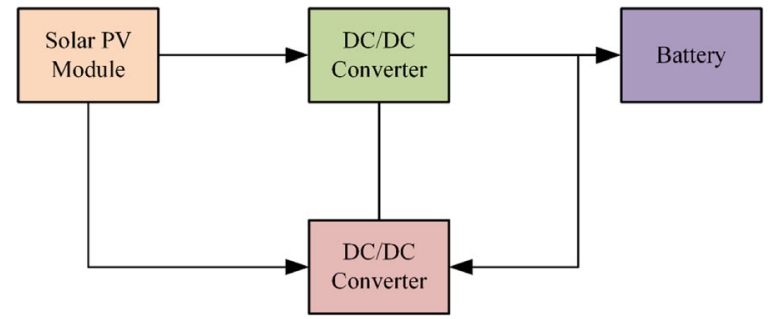

Fig. 3 Block diagram of PV system with MPPT charger

circuits of a solar cell are shown. From Fig. 1b the generated current (I) by the PV cell is given by

$$
\begin{aligned}
& I=I_{s c}-I_{d}-I_{s h} \\
& I=I_{s c}-\left(\frac{V+I R_{s}}{R_{s h}}\right)-I_{o}\left(e^{\frac{v+I R_{s}}{n T}}-1\right)
\end{aligned}
$$

Where $V_{T}$ is the thermal voltage, $R_{s}$ and $R_{s h}$ represent the internal series and parallel resistances, respectively. $I_{s c}$ is the short-circuit current, $I_{o}$ is the reverse saturation current, $V_{D}$ is the voltage across the diode, $I$ is the current output and $n$ is the ideality factor of the diode (1 2).

A simplified model after neglecting the shunt resistance is shown in Fig. 1a, and accordingly the following equation can be derived.

$$
I=I_{s c}-I_{o}\left(e^{\frac{v+I R_{s}}{n V_{T}}}-1\right)
$$

PV cell output voltage can be found by considering $T=K T / q$ in (3) as

$$
V=-I R_{s}+\frac{A K T}{q} \ln \frac{\left(I_{s c}+I_{o}-I\right)}{I_{o}}
$$

\subsection{PV cell I-V curve}

PV cells have nonlinear I-V characteristic, which change with irradiation level and temperature. For standard temperature $\left(25{ }^{\circ} \mathrm{C}\right)$ and irradiation level $\left(1000 \mathrm{~W} / \mathrm{m}^{2}\right)$, the I-V curve of a PV cell is shown in Fig. 2, where the maximum power point is always at the knee of the curve as indicated.

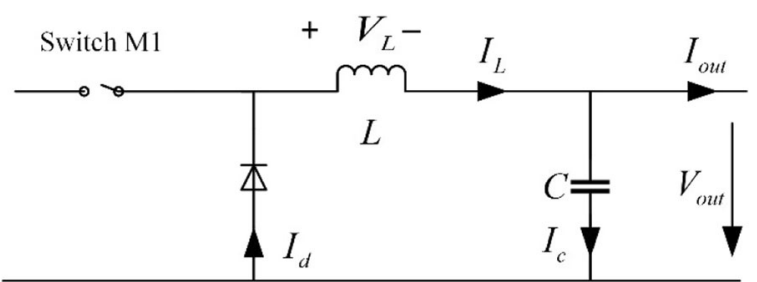

Fig. 4 Electrical Model of DC/DC Buck converter 


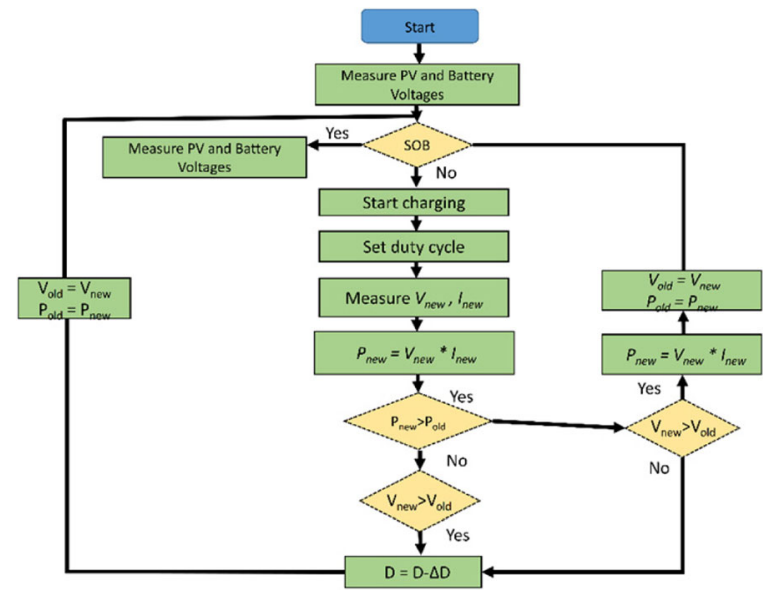

Fig. 5 Used P\&O algorithm

\subsection{Block diagrams of the proposed system with MPPT charge controller}

An off-grid PV system usually consists of PV modules and batteries, which are connected through charge controllers. To improve system efficiency, an MPPT charge controller has been introduced as shown in the block diagram in Fig. 3. The MPPT charge controller is connected between the PV module and battery to extract maximum power from the PV module and deliver to the battery.

\subsection{DC/DC converter}

$\mathrm{DC} / \mathrm{DC}$ converters convert one level of DC voltage to another. In the designed project, a buck DC/DC converter is used which step down the voltage and step up the current. The basic components used in the converter are a power semiconductor switch $\left(\mathrm{M}_{1}\right)$, an inductor $(\mathrm{L})$, a diode (D) and a capacitor (C) as shown in Fig. 4.

A buck DC/DC converter has two operation modes associated to switch $\mathrm{M}_{1}$ being closed and opened, respectively. When the switch $\mathrm{M}_{1}$ is closed at time $t=0$, the input power is supplied to the load through inductor $\mathrm{L}$. At that time the diode is reverse biased, and $\mathrm{I}_{\mathrm{L}}$ current increases at the rate of:

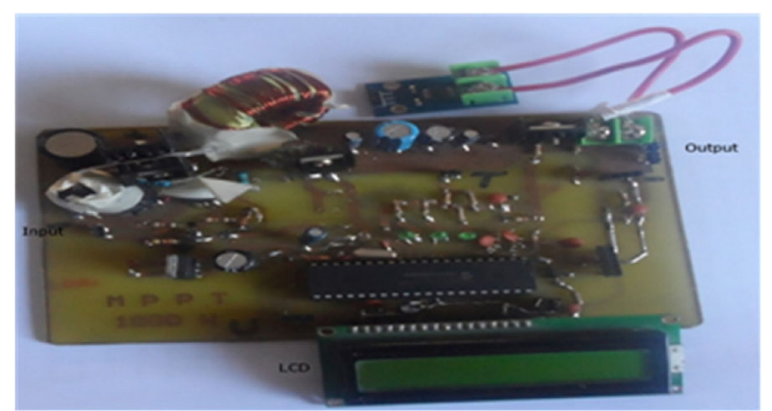

Fig. 6 Picture of the designed MPPT
Table 1 Solar panel specification at $1000 \mathrm{~W} / \mathrm{m}^{2}$ and cell temperature of $25^{\circ}$

\begin{tabular}{ll}
\hline Parameters & Specification \\
\hline Peak Power $\left(P_{\max }\right)$ & $200 \mathrm{~W}$ \\
Open circuit voltage $/ N_{\mathrm{oc}}$ & $32.4 \mathrm{~V}$ \\
Max power voltage $\mathrm{N}_{\mathrm{mp}}$ & $27 \mathrm{~V}$ \\
Short circuit current $/ \mathrm{I}_{\mathrm{sc}}$ & $8 \mathrm{~A}$ \\
Max power current $/ /_{\mathrm{mp}}$ & $7.41 \mathrm{~A}$ \\
\hline
\end{tabular}

$$
\frac{d i_{L}}{d t}=\frac{v_{L}}{L}=\frac{v_{\text {in }}-v_{o}}{L}, t \in[0, D t]
$$

During this period inductor $L$ is charging. At time $t=$ $t_{1}$, switch M1 opens and the energy stored in the inductor is delivered to the load through diode $\mathrm{D}$ which becomes forward biased. The inductor is now discharging and $I_{L}$ decreases at the rate of.

$$
\frac{d i_{L}}{d t}=\frac{v_{L}}{L}=\frac{-v_{o}}{L}, t \in[D t, T]
$$

The diode remains in forward biased until M1 switch is closed. During one switching cycle, the average inductor voltage $v_{L}$ is zero under steady state. Since there are two states of $v_{L}$, both having constant voltage, the average value of the output voltage is given by

$$
v_{o}=\frac{1}{T} \int_{0}^{T} v_{o}(t) d t=\frac{1}{T} \int_{0}^{D t} v_{i n}(t) d t=D v_{\text {in }}
$$

Hence,

$$
v_{o}=D v_{\text {in }}
$$

Duty cycle (D) is given as:

$$
D=\frac{t_{\text {on }}}{t_{\text {on }}+t_{\text {off }}}
$$

For continuous conduction mode, the required minimum value of inductance can be expressed as:

$$
L=\frac{v_{o}(1-D)}{2 I_{o} f_{P W M}}
$$

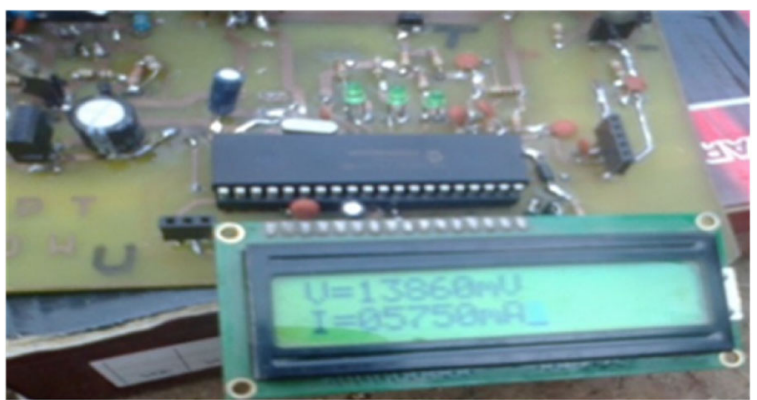

Fig. 7 Value of output Voltage and Current on LCD 
The capacitor value can be calculated considering the output ripple voltage as

$$
C=\frac{i_{o}}{4 \Delta V f_{P W M}}
$$

Where $i_{o}$ is the output current, $f_{P W M}$ is the switching frequency and $\Delta V$ is the output voltage ripple.

\subsection{Maximum power point tracking}

To harvest maximum power from the PV panel a charge controller with MPPT capability is proposed in this paper. The two broad categories of MPPT techniques are the indirect techniques and direct techniques. Indirect techniques include the fixed voltage, open circuit voltage and short circuit current methods. In this kind of tracking, simple assumption and periodic estimation of the MPPT are made with easy measurements. For example, the fixed voltage technique only adjusts the operating voltage of the solar PV module at different seasons with the assumption of higher MPP voltages in winter and lower MPP voltages in summer at the same irradiation level. This method is not accurate because of the changing of irradiation and temperature level within the same season.

a

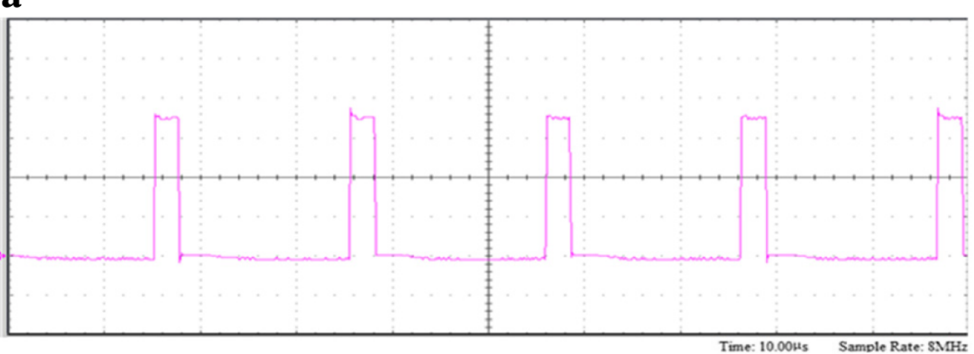

$\mathbf{b}$

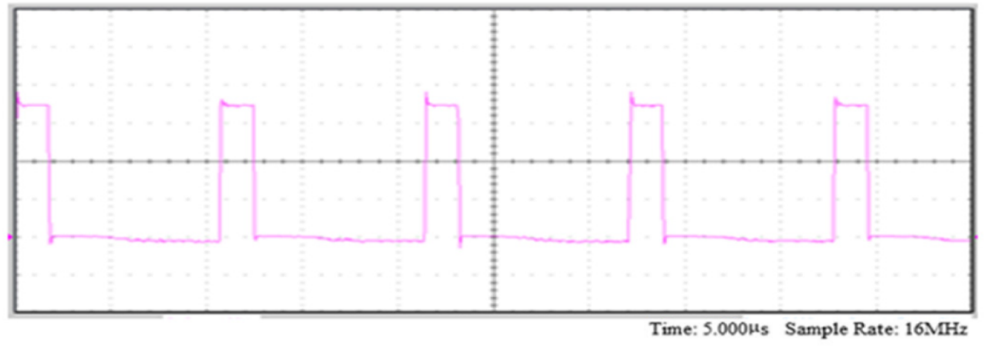

c

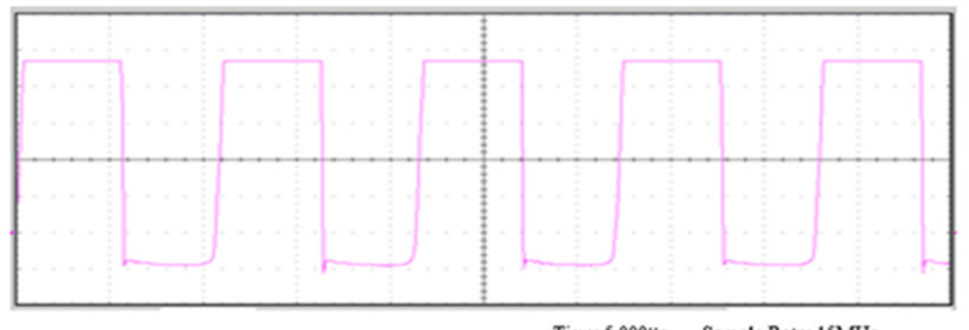

Time: $5000 \mu_{\text {s }}$ Sample Rate: $15 \mathrm{MHz}$

d

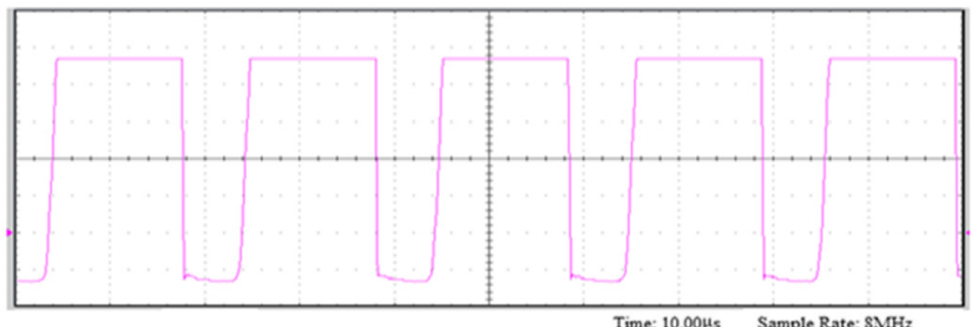

Fig. 8 Changing Duty cycles at different power $(\mathbf{a}, \mathbf{b}, \mathbf{c}$ and $\mathbf{d}$ ) (time ranges from 5-10 $\mu$ s and sample rate from 8-16 MHz) 
Another most common indirect MPPT technique is the open circuit voltage $(\mathrm{OV})$ method. In this method, it is assumed that:

$$
V_{M M P}=k \cdot V_{o c}
$$

Where $\mathrm{k}$ is a constant and its value for crystalline silicon is usually to be around 0.7 to 0.8 . This technique is simple and is easier to implement compared to other techniques. However the constant $\mathrm{k}$ is just an approximation Leading to reduced efficiency, and each time the system needs to find the new open circuit voltage $\left(\mathrm{V}_{\text {out }}\right)$ when the illumination condition changes. To find the new open circuit voltage, each time the load connected to the PV module must be disconnected causing power loss. Direct MPPT methods measure the current and voltage or power and thus are more accurate and have faster response than the indirect methods. Perturb and observe $(\mathrm{P} \& \mathrm{O})$ is one of the direct MPPT techniques, which is used here with some modifications.

\subsection{Perturb and observe algorithm (P\&O)}

Typically, $\mathrm{P} \& \mathrm{O}$ method is used for tracking the MPP. In this technique, a minor perturbation is introduced to, cause the power variation of the PV module. The PV output power is periodically measured and compared with the previous power. If the output power increases, the same process is continued otherwise perturbation is reversed. In this algorithm perturbation is provided to the PV module or the array voltage. The PV module voltage is increased or decreased to check whether the power is increased or decreased. When an increase in voltage leads to an increase in power, this means the operating point of the PV module is on the left of the MPP [26]. Hence further perturbation is required towards the right to reach MPP. Conversely, if an increase in voltage leads to a decrease in power, this means the operating point of the PV module is on the right of the MPP and hence further perturbation towards the left is required to reach MPP. The flow chart of the adopted P\&O algorithm for the charge controller is given in Fig. 5. When the MPPT charge controller is connected between the
PV module and battery, it measures the PV and battery voltages. After measuring the battery voltage, it determines whether the battery is fully charged or not. If the battery is fully charged (12.6 V at the battery terminal) it stops charging to prevent battery over charging. If the battery is not fully charged, it starts charging by activating the DC/DC converter. The microcontroller will then calculate the existing power $P_{\text {new }}$ at the output by measuring the voltage and current, and compare this calculated power to the previous measured power $P_{\text {old }}$. If $P_{\text {new }}$ is greater than $P_{\text {old }}$, the PWM duty cycle is increased to extract maximum power from the PV panel. If $P_{\text {new }}$ is less than $P_{\text {old }}$, the duty cycle is reduced to ensure the system to move back to the previous maximum power. This MPPT algorithm is simple, easy to implement, and low cost with high accuracy [26-28].

\subsection{MPPT charge controller hardware}

The proposed MPPT charge controller is designed using the Altium Designer software, an electronic design automation for printed circuit board (PCB), field -programmable gate array (FPGA) and embedded software design. The picture of the designed hardware shown in Fig. 6.

The developed MPPT charge controller is connected between a PV module and battery following the specifications given in Table 1. In the first observation, the output power of the PV module and the MPPT controller are calculated. The measured output voltage and current of the MPPT controller are shown in Fig. 7, and the output power for the PV module and the MPPT controller are $86.05 \mathrm{~W}$ and $79.69 \mathrm{~W}$, respectively.

During the tests, the weather was partially cloudy and the output of the PV module varied. The output power of the MPPT controller mainly depends on the PWM duty cycle, which is shown in Fig. 8.

Two types of experimental testing were performed. Conventional PWM charge controller was connected to one panel and the MPPT charge controller was connected to the other panel with the same specifications. To check the behavior of the controllers at different weather conditions and irradiance levels, three results of input and output power were from $2 \mathrm{pm}$ to $3: 30 \mathrm{pm}$ at

Table 2 Comparison of PWM and designed MPPT charge controller

\begin{tabular}{|c|c|c|c|c|c|c|c|c|}
\hline & \multirow[b]{2}{*}{ time } & \multicolumn{2}{|c|}{ Input Reading } & \multicolumn{4}{|c|}{ Output Reading } & \multirow[b]{2}{*}{ Efficiency (\%) } \\
\hline & & $I_{p v(A)}$ & $V_{p v}(n)$ & $P_{p v}(w)$ & $\mathrm{I}_{\text {out }(A)}$ & $V_{\text {out }}(M)$ & $P_{\text {out }(M)}$ & \\
\hline \multirow[t]{3}{*}{ PWM charge controller } & $14: 00$ & 7.8 & 14.4 & 112.32 & 5.1 & 12.6 & 64.26 & $57.21 \%$ \\
\hline & $14: 30$ & 6.2 & 14.1 & 86.05 & 4.5 & 12.5 & 56.25 & $65.36 \%$ \\
\hline & 15:00 & 4.5 & 13.9 & 63.45 & 3.92 & 12.7 & 49.7 & $78.32 \%$ \\
\hline \multirow[t]{3}{*}{ MPPT charge controller } & $14: 00$ & 7.8 & 14.4 & 112.32 & 6.202 & 14.1 & 87.45 & $77.85 \%$ \\
\hline & $14: 30$ & 6.2 & 14.1 & 86.05 & 5.75 & 13.86 & 79.69 & $92.60 \%$ \\
\hline & 15:00 & 4.5 & 13.9 & 63.45 & 3.95 & 14.01 & 55.58 & $87.59 \%$ \\
\hline
\end{tabular}




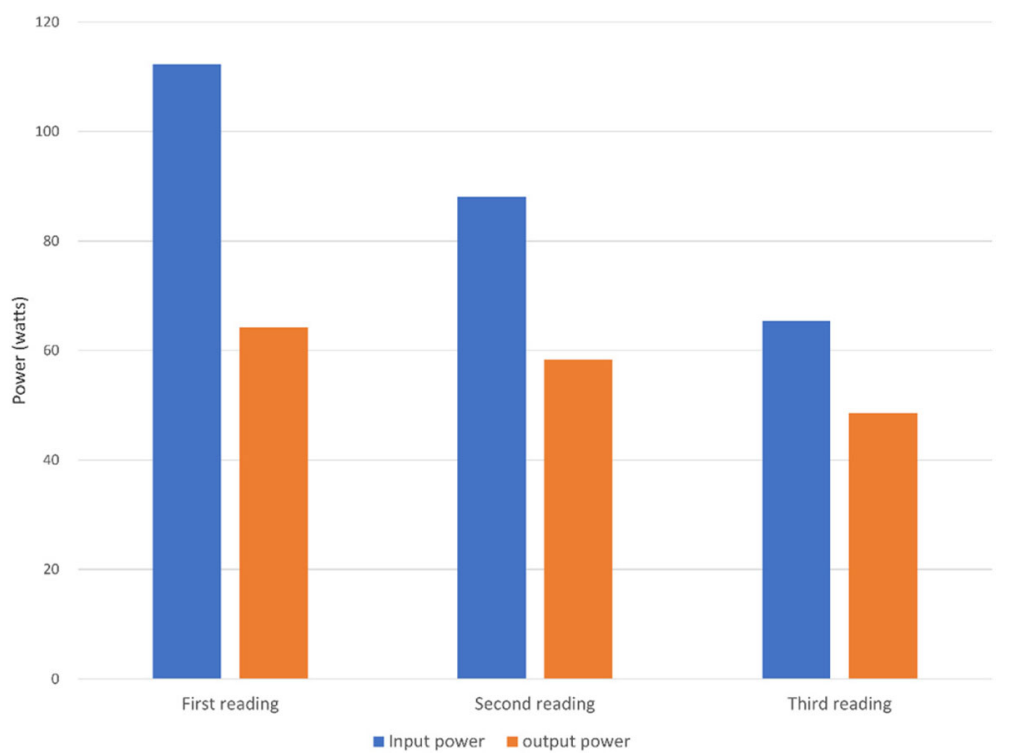

Fig. 9 Input and output power: when conventional PWM charge controller is connected

30 min interval as listed in Table 2. The efficiencies shown in Table 2 were determined according to the measured input and output power.

As shown in Table 2, compared to the conventional charge controller, the developed MPPT charge controller significantly improve efficiency for each of the test time. These results prove that maximum power is harvested from the PV module by using the MPPT charge controller. When the battery is fully charged $(12.6 \mathrm{~V})$, the MPPT charge controller still provide low current ( $5 \mathrm{~mA})$ to avoid self-discharge of the battery. Hence, the overall efficiency is improved by using the MPPT charge controller. These results are also depicted in Figs. 9 and 10.

\section{Conclusion}

To harvest maximum power from a PV module, MPPT based on modified $\mathrm{P} \& \mathrm{O}$ algorithm is implemented in this paper. The hardware consists of a high efficiency DC/DC buck converter and a microcontroller based MPPT controller, and is tested for battery charging. A conventional charge controller and the designed charge controller are compared when charging a $12 \mathrm{~V}$ battery from a $200 \mathrm{~W}$ solar PV module. It shows that the modified $\mathrm{P} \& \mathrm{O}$ algorithm provides an efficient and reliable maximum power tracking performance under rapid change in irradiance and temperature conditions. The experimental results show that the proposed system is more efficient than the conventional design.

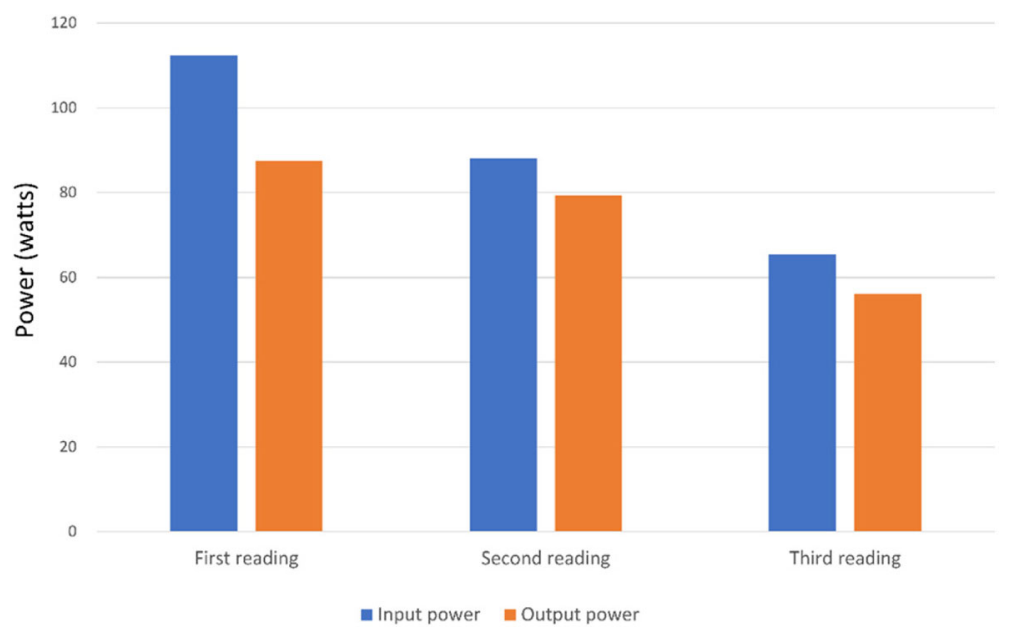

Fig. 10 Input and output power when: MPPT charge controller is connected 


\section{Abbreviations}

MPP: Maximum power point; MPPT: Maximum Power Point Tracker; P\&O: Perturb and observe; PCB: Printed circuit board; PV: Photovoltaic; PWM: Pulse width modulation

\section{Funding}

2016 national key R \& D program of China to support low-carbon Winter Olympics of integrated smart grid demonstration project (2016YFB0900501).

\section{Availability of data and materials}

All data is given in the paper or properly cited wherever necessary.

\section{About the Authors}

Salman Salman (1987-), male, PHD and Engineer, He received BE degree. From Baluchistan university of engineering and technology in electrical engineering; the MS degree from CIIT Islamabad, Pakistan in 2015. He is currently doing PhD from NCEPU in Major power system.

Xin Al (1964-), male, PHD and Professor, he received the B.S. degree from the Nanjing Institute of Technology, Nanjing, China (now Southeast University); the M.S. degree from the China Electric Power Research Institute, Beijing, China; and the Ph.D. degree from North China Electric Power University (NCEPU), Beijing, in 1985, 1988, and 1999, respectively, all in electrical engineering. He was a Senior Research Scholar with Brunel University, London, U.K., in 2003. He was the Director of the Institute of Power Systems, NCEPU, where he was engaged in research and teaching on power system and automation. He is currently a Professor and a Doctoral Tutor with the School of Electrical and Electronic Engineering, NCEPU. His current research interests include power system analysis and control, and transactive energy. Zhouyang Wu (1994-), male, MS and Engineer, he received B.S. degree from BUAA, now working M.S. degree in electrical engineering at NCEPU in electrical engineering, major in the planning of power system.

\section{Authors' contributions}

SS contributed to analysis, modelling and manuscript preparation, Professor Al brought up the original conception and guide the study as a corresponding author, ZW participated in revision and typesetting of the manuscript. All authors read and approved the final manuscript.

\section{Authors' information}

Salman Salman is currently pursuing Ph.D. from Department of electrical engineering, North china electric power university, Beijing, China. He received MS degree with Honors in Electrical Power Engineering from Comsats institute of information technology, Islamabad, Pakistan. He received $B E$ degree form Baluchistan University of engineering and technology, khuzdar, Pakistan. His area of interest is power System Protection, Micro grids, DER's, Renewable Energy Resources, Transactive control and Electrical vehicle-grid integration.

Ai Xin, he received B.S. degree from the Nanjing Institute of Technology, Nanjing, China (now Southeast University); the M.S. degree from the China Electric Power Research Institute, Beijing, China; and the Ph.D. degree from North China Electric Power University (NCEPU), Beijing, in 1985, 1988, and 1999, respectively, all in electrical engineering. He was a Senior Research Scholar with Brunel University, London, U.K., in 2003. He was the Director of the Institute of Power Systems, NCEPU, where he was engaged in research and teaching on power system and automation. He is currently a Professor and a Doctoral Tutor with the School of Electrical and Electronic Engineering, NCEPU. His current research interests include power system analysis and control, and transactive energy.

Zhouyang Wu, he received B.S. degree from BUAA, now working M.S. degree in electrical engineering at NCEPU in electrical engineering, major in the planning of power system.

\section{Competing interests}

The authors declare that they have no competing interests.
Received: 1 July 2017 Accepted: 31 July 2018

Published online: 17 August 2018

\section{References}

1. Leva, S., \& Zaninelli, D. (2006). Technical and financial analysis for hybrid photovoltaic power generation systems. WSEAS Transactions on Power Systems, 5(1), 831-838.

2. Contino, R., Leva, S., \& Zaninelli, D. (2007). Integrated renewable sources for supplying remote power systems. WSEAS Transactions on power systems, 2(2), 41-48.

3. Faranda, R., Leva, S., \& Maugeri, V. (2008). MPPT techniques for PV systems: Energetic and cost comparison. In Power and Energy Society General Meeting-Conversion and Delivery of Electrical Energy in the 21st Century, 2008 IEEE (pp. 1-6). IEEE.

4. Dubey, S., Sarvaiya, J. N., \& Seshadri, B. (2013). Temperature dependent photovoltaic (PV) efficiency and its effect on PV production in the world-a review. Energy Procedia, 33, 311-321.

5. Hamrouni, N., Jraidi, M., \& Chérif, A. (2008). Solar radiation and ambient temperature effects on the performances of a PV pumping system. Rev Energ Renouv, 11(1), 95-106.

6. Sivakumar, P., Kader, A. A., Kaliavaradhan, Y., \& Arutchelvi, M. (2015). Analysis and enhancement of PV efficiency with incremental conductance MPPT technique under non-linear loading conditions. Renew Energy, 81, 543-550.

7. Ishaque, K., \& Salam, Z. (2013). A review of maximum power point tracking techniques of PV system for uniform insolation and partial shading condition. Renew Sust Energ Rev, 19, 475-488.

8. Bendib, B., Belmili, H., \& Krim, F. (2015). A survey of the most used MPPT methods: Conventional and advanced algorithms applied for photovoltaic systems. Renew Sust Energ Rev, 45, 637-648.

9. Ramli, M. Z., \& Salam, Z. (2014). A simple energy recovery scheme to harvest the energy from shaded photovoltaic modules during partial shading. IEEE Trans Power Electron, 29(12), 6458-6471.

10. De Brito, M. A. G., Galotto, L., Sampaio, L. P., e Melo, G. D. A., \& Canesin, C. A. (2013). Evaluation of the main MPPT techniques for photovoltaic applications. IEEE Trans Ind Electron, 60(3), 1156-1167.

11. Bennett, T., Zilouchian, A., \& Messenger, R. (2012). Photovoltaic model and converter topology considerations for MPPT purposes. Sol Energy, 86(7), 2029-2040.

12. Farahat, M. A., Metwally, H. M. B., \& Mohamed, A. A. E. (2012). Optimal choice and design of different topologies of DC-DC converter used in PV systems, at different climatic conditions in Egypt. Renew Energy, 43, 393-402.

13. Gokmen, N., Karatepe, E., Ugranli, F., \& Silvestre, S. (2013). Voltage band based global MPPT controller for photovoltaic systems. Sol Energy, 98, 322-334.

14. Eltawil, M. A., \& Zhao, Z. (2013). MPPT techniques for photovoltaic applications. Renew Sust Energ Rev, 25, 793-813.

15. Quoc, D. P., Nhat, Q. N., Vu, N. T. D., Bao, A. N., \& Lee, H. H. (2011). The new combined maximum power point tracking algorithm using fractional estimation in photovoltaic systems. In Power Electronics and Drive Systems (PEDS), 2011 IEEE Ninth International Conference on (pp. 919-923). IEEE.

16. Noguchi, T., Togashi, S., \& Nakamoto, R. (2002). Short-current pulse-based maximum-power-point tracking method for multiple photovoltaic-andconverter module system. IEEE Trans Ind Electron, 49(1), 217-223.

17. Chekired, F., Larbes, C., Rekioua, D., \& Haddad, F. (2011). Implementation of a MPPT fuzzy controller for photovoltaic systems on FPGA circuit. Energy Procedia, 6, 541-549.

18. Radjai, T., Rahmani, L., Mekhilef, S., \& Gaubert, J. P. (2014). Implementation of a modified incremental conductance MPPT algorithm with direct control based on a fuzzy duty cycle change estimator using dSPACE. Sol Energy, 110, 325-337.

19. Femia, N., Petrone, G., Spagnuolo, G., \& Vitelli, M. (2009). A technique for improving P\&O MPPT performances of double-stage grid-connected photovoltaic systems. IEEE Trans Ind Electron, 56(11), 4473-4482.

20. Patel, H., \& Agarwal, V. (2008). Maximum power point tracking scheme for PV systems operating under partially shaded conditions. IEEE Trans Ind Electron, 55(4), 1689-1698.

21. Elgendy, M. A., Zahawi, B., \& Atkinson, D. J. (2012). Assessment of perturb and observe MPPT algorithm implementation techniques for PV pumping applications. IEEE transactions on sustainable energy, 3(1), 21-33.

22. Suwannatrai, P., Liutanakul, P., \& Wipasuramonton, P. (2011). Maximum power point tracking by incremental conductance method for photovoltaic systems with phase shifted full-bridge dc-dc converter. In Electrical Engineering/Electronics, Computer, Telecommunications and Information Technology (ECTI-CON), 2011 8th International Conference on (pp. 637-640). IEEE. 
23. Selvan, D. S. (2013). Modeling and simulation of incremental conductance MPPT algorithm for photovoltaic applications. International Journal of Scientific Engineering and Technology, 2(7), 681-685.

24. Ankaiah, B., \& Nageswararao, J. (2013). MPPT algorithm for solar photovotaic cell by incremental conductance method. International Journal of Innovations in Engineering and Technology, 2(1), 17-23.

25. Masoum, M. A., Badejani, S. M. M., \& Fuchs, E. F. (2004). Microprocessorcontrolled new class of optimal battery chargers for photovoltaic applications. IEEE Transactions on energy conversion, 19(3), 599-606.

26. Dabra, V., Paliwal, K. K., Sharma, P., \& Kumar, N. (2017). Optimization of photovoltaic power system: A comparative study. Protection and Control of Modern Power Systems, 2(1), 3.

27. Kumari, J. S., Babu, D. C. S., \& Babu, A. K. (2012). Design and analysis of P\&O and IP\&O MPPT techniques for photovoltaic system. International Journal of Modern Engineering Research, 2(4), 2174-2180.

28. Sera, D., Teodorescu, R., Hantschel, J., \& Knoll, M. (2008). Optimized maximum power point tracker for fast changing environmental conditions. In Industrial Electronics, 2008. ISIE 2008. IEEE International Symposium on (pp. 2401-2407). IEEE.

\section{Submit your manuscript to a SpringerOpen ${ }^{\circ}$ journal and benefit from:}

- Convenient online submission

- Rigorous peer review

- Open access: articles freely available online

High visibility within the field

- Retaining the copyright to your article

Submit your next manuscript at $\boldsymbol{\nabla}$ springeropen.com 